\title{
Bioaccumulation and health risk assessment of severe metal pollution of street dust from various urban regions in Baghdad, Iraq
}

\author{
Salwan Ali Abed ${ }^{1, *}$, Safaa A Kadhum ${ }^{2}$, Salam Hussein Ewaid ${ }^{3}$, and Nadhir Al-Ansari ${ }^{4}$ \\ ${ }^{1,2}$ College of Science, University of Al-Qadisiyah, P.O. Box.1895, Iraq \\ ${ }^{3}$ Technical Institute of Shatra, Southern Technical University, Iraq \\ ${ }^{4}$ Luleå University of Technology, 97187 Luleå, Sweden
}

\begin{abstract}
This study sought to define the metals bioaccumulation from street dust in Baghdad, Iraq for the first time. The samples were collected that research the levels, sources, and health hazard model $\mathrm{Cd}, \mathrm{Cr}, \mathrm{Zn}$ and $\mathrm{Cu}$. The geo accumulation Index (Igeo) found that the contamination level for $\mathrm{Cd}$ was moderately to strongly polluted in Karada, Jihad and Kinidi streets. Hence, it is important to measure the level of cadmium in the local environment. The relative bioaccumulation of chromium was high in Jadriyah Street (87.2\%). The PCA showed two major sources of these minerals in Baghdad road dust that $\mathrm{Cd}, \mathrm{Zn}$ are likely to originate from tire wear, brake wear and vehicular emissions as well as the fact that $\mathrm{Cr}$ and $\mathrm{Cu}$ originate from metalprocessing industries. Assessing hazard to human health utilized measure population show suggested both non-carcinogenic and carcinogenic hazards minerals Baghdad road dust harmless to human environment.
\end{abstract}

\section{Introduction}

Industrialization and urbanization in Baghdad are major sources of air contamination constituting heavy metal content in urban dust due to human activity, such as traffic exhaust fumes, garbage, city construction, power generation plants and industrial production that are giving way to the reduction of the quality of urban environments [1]. Many developed countries suffer from various grades of weighty metal pollution in road dust, caused through anthropogenic, natural factors [2]. Furthermore, weighty metals could collect in urban street dust through point and non-point pollution sources through absorption and atmospheric deposition [3]. As a consequence, necessarily to check heavy metal pollution/contamination heavy populated cities.

Several researches in road dust concentrate on weighty Minerals contents, researchers found metals in road dust higher than those in soil, trace elements in street dust perhaps facilely absorbed by people over assimilation, inspiration and touching the skin [4].

Therefore, the dust in urban cities can be harmful for human health especially in densely populated urban settings. Although many studies have proven heavy metals pollution in streets [5], metals bioaccumulation investigations are important to the assessment of environmental and health risks. Using bioaccumulation is accurate and more feasible to measure the health risks as heavy metals dissolve in gastrointestinal fluid and simulate Biochemistry situations in people digestive [6].
This research, we present the results of a quantitative measurement of metal bioaccumulation from Baghdad. Therefore, this study objective is (i) to define the sources and concentration of total and bioaccumulation of minerals in road dust in various civilian environments Baghdad and (ii) to estimate health hazards to people in Baghdad.

\section{Materials and methods}

\subsection{Search space}

Baghdad capital and great city in Iraq, with a population of about 8.7 million. The urbanization and industrialization in the city has led to increasing numbers of vehicles on the roads. Moreover, rebuilding efforts in Iraq devoted to the reconstruction/rehabilitation and repair of sorely damaged urban infrastructure can contribute to higher levels of dust in the atmosphere/environment/air. Baghdad has three power plants and around 16 industrial what? That includes oil refinery, chemical, steel mill, cement plant, textile, plastic manufacturing. The climate in Baghdad is arid to semiarid and dry and hot in summer $\left(50^{\circ} \mathrm{C}\right) \mathrm{cool}$ in winter $\left(4^{\circ} \mathrm{C}\right)$; Annual rainfall nearly $151.8 \mathrm{~mm}$ (Al-Adili, 2005). Samples were collected from different Baghdad suburbs including: Yarmouk (S1), Adamiyah (S2), Shaab (S3), Wazireya (S4), Mansour (S5), Kindi (S6), Jihad (S7), Jadriyah (S8), Dora (S9), Karada (S10) (Figure 1).

\footnotetext{
* Corresponding author: salwan.abed@qu.edu.iq
} 


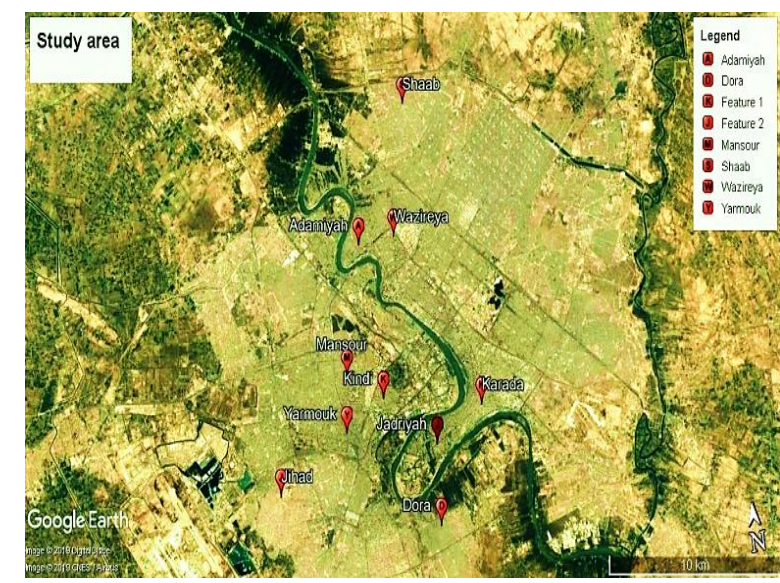

Fig.1. Sampling location at Baghdad city, Iraq

\subsection{Street dust sampling}

The street dust was collected according to TrujilloGonzález [7]. The street dust samples $(n=30)$ were collected in April and May 2018. The sites, designation, description, and coordinates of samples collected are shown in Table.1. A frame of $0.25 \mathrm{~m} 2$, clump and a plastic scoop were utilized gather the dust elements from Baghdad streets. Polyethylene bags were used to store dust samples collected. The bags were labeled and carefully transported to the laboratory. In order to get a uniform mass of samples, the dust was desiccated at room heat and identical $2 \mathrm{~mm}$ colander based on former test [8].

Table 1. The coordinates and characterization for all specimen centers

\begin{tabular}{|c|c|c|c|}
\hline Centers & $\begin{array}{c}\text { Specimen } \\
\text { enters }\end{array}$ & Coordinates & Characterization \\
\hline 1 & Yarmouk & $\begin{array}{l}33^{\circ} 17^{\prime} 44.22^{\prime \prime} \mathrm{N} \\
44^{\circ} 20^{\prime} 29.27^{\prime \prime} \mathrm{E}\end{array}$ & Hospital area \\
\hline 2 & Adamiyah & $\begin{array}{l}33^{\circ} 22^{\prime} 6.16^{\prime \prime} \mathrm{N} \\
44^{\circ} 21^{\prime} 44.19^{\prime \prime} \mathrm{E}\end{array}$ & Residential area \\
\hline 3 & Shaab & $\begin{array}{l}33^{\circ} 25^{\prime} 14.30^{\prime \prime} \mathrm{N} \\
44^{\circ} 23^{\prime} 58.48^{\prime \prime} \mathrm{E}\end{array}$ & Residential area \\
\hline 4 & Wazireya & $\begin{array}{l}33^{\circ} 22^{\prime} 8.51^{\prime \prime} \mathrm{N} \\
44^{\circ} 23^{\prime} 4.71^{\prime \prime} \mathrm{E}\end{array}$ & Industrial area \\
\hline 5 & Mansour & $\begin{array}{l}33^{\circ} 19^{\prime} 3.09^{\prime \prime} \mathrm{N} \\
44^{\circ} 20^{\prime} 44.76 " \mathrm{E}\end{array}$ & $\begin{array}{c}\text { Commercial } \\
\text { area }\end{array}$ \\
\hline 6 & Kindi & $\begin{array}{l}33^{\circ} 18^{\prime} 21.92^{\prime \prime N} \\
44^{\circ} 22^{\prime} 0.32^{\prime \prime} \mathrm{E} \\
\end{array}$ & Hospital area \\
\hline 7 & Jihad & $\begin{array}{l}33^{\circ} 16^{\prime} 32.96 " \mathrm{~N} \\
44^{\circ} 17^{\prime} 47.51 " \mathrm{E}\end{array}$ & $\begin{array}{c}\text { Commercial } \\
\text { area }\end{array}$ \\
\hline 8 & Jadriyah & $\begin{array}{l}33^{\circ} 17^{\prime} 2.79^{\prime \prime} \mathrm{N} \\
44^{\circ} 23^{\prime} 48.76^{\prime \prime} \mathrm{E}\end{array}$ & Residential area \\
\hline 9 & Dora & $\begin{array}{l}33^{\circ} 15^{\prime} 7.12^{\prime \prime} \mathrm{N} \\
44^{\circ} 23^{\prime} 36.95^{\prime \prime} \mathrm{E} \\
\end{array}$ & $\begin{array}{c}\text { Power } \\
\text { generation plant }\end{array}$ \\
\hline 10 & Karada & $\begin{array}{l}33^{\circ} 17^{\prime} 46.19^{\prime \prime} \mathrm{N} \\
44^{\circ} 25^{\prime} 37.64^{\prime \prime} \mathrm{E}\end{array}$ & $\begin{array}{c}\text { Commercial } \\
\text { area }\end{array}$ \\
\hline
\end{tabular}

\subsection{Sample digestion and analysis}

The samples of dry dust $(0.5 \mathrm{~g})$ were screened from a 75 $\mu \mathrm{m}$ network sieve and a $10 \mathrm{~mL}$ solution of 3: 1 mixture ( $\mathrm{HCl} / \mathrm{HNO} 3)$ was used to digest the samples combine to all experiment pipe. The pipe mixtures were neglect to room heat throughout the night to avoid lost minerals. The tube test of the samples was wrapped in air capacitor, heated at $80^{\circ} \mathrm{C}$ two hours. Samples were then filtered into $50 \mathrm{~mL}$ sterile flasks [9]. The samples were then cooled and specimens w mingled $50 \mathrm{~mL}$ double distilled water (DDW). SBET performed using dust-dried air $(0.5 \mathrm{~g})$ with a sieve (75 microns) in dismiss pipe. Specimens mingled50 $\mathrm{mL}$ of the gastric sol 0.4 glycin $\mathrm{pH}=1.5$. intensified hydrochloric acid. two tubes were finally rotated $30 \mathrm{rpm}$ one hour at $37{ }^{\circ} \mathrm{C}$ centrifuged $3500 \mathrm{~g} 15 \mathrm{~min}$. extract samples were then purified over $0.45 \mu \mathrm{m}$ drum candidate of acetate. After $\mathrm{pH}$ determination, contagious sol samples preserved in the fridge $4{ }^{\circ} \mathrm{C}$. Dust specimens measured concentrations of trace minerals using acetylene atomic absorption flame.

The data obtained are displayed on dry weight basis (mg/kg dry weight). All glass wares were soaked in acid wash $(10 \%$ HNO3) for at least $24 \mathrm{~h}$ to avoid contamination and later rinsed with double distilled water and air dried before use. Quality and quantity insurance of heavy metals analysis were conducted to ensure setting and regulation of the analytical method, through generated calibration curves by analyzing multiple-level calibration standards Blank was used to zero the instrument and a quality control samples were analyzed after every four samples during metal analysis.

\subsection{Health risk assessment}

Due to residents livening close the main streets of Baghdad the health hazard estimation was conducted present research in order to enumerate detection metals hazard to human from dust via ingesting contaminated. The chemical every day assimilation (CDI) (mg kg-1 day-1) of metals from assimilation of street dusts was calculated based on following equation:

$$
\mathrm{CDI}=\mathrm{C} \text { dust } \times \frac{\mathrm{EF} \times \mathrm{ED} \times \mathrm{IR}}{\mathrm{BW} \times \mathrm{AT}} \times 10-6
$$

Where IR assimilation average $200 \mathrm{mg}$ /day dust daily per kids and $100 \mathrm{mg}$ daily per adolescents, detector hesitancy (EF) at 350 days year -1 [10], the exposition period (ED) was 6 years for children and 30 years for adults, body weight (BW) per kids was $15 \mathrm{~kg}$ and $70 \mathrm{Kg}$ per adolescents calculated of rate time $(\mathrm{AT})$ was $\mathrm{ED} \times 365$ no carcinogens and $70 \times 365=25,550$ days for carcinogens.

Possibility carcinogenic and non-carcinogenic hazards per single minerals evaluated US EPA (2007) protocol and followed by [11] utilizing next one formulas:

Carcinogenic hazard $(\mathrm{CR})=\mathrm{CDI} \times \mathrm{RBA} \times \mathrm{CSF}$

Risk division $(\mathrm{HQ})=(\mathrm{CDI} \times \mathrm{RBA}) / \mathrm{RFD}$

RBA $\%=\frac{\text { SBET Metal }}{\text { Contant metal }} \times 100$

$\mathrm{HI}=\sum \mathrm{HQi}$

Signal dosage (RfD) (mg kgl day1) and cancer decline factor (CSF) (mg kg1 day1) were calculated according to U.S. Environmental Protection Agency United States Department of Energy. Accordingly, the values of RfD were 0.0010 for $\mathrm{Cd}, 0.0030$ for $\mathrm{Cr}, 0.3$ for $\mathrm{Zn}$ and 0.037 for $\mathrm{Cu}$ [12], while values of CSF were 6.3 for $\mathrm{Cd}$, and 5.00E01 for $\mathrm{Cr}$. The calculated of prorated bioaccumulation adjustment (RBA) based on the rate of clearly bioaccumulation essence test (SBET) heavy metals extracted to their total concentrations in dust.

Risk division (HQ) rate indicate to beginning reference rate proposed by US EPA as the admissibility for noncarcinogenic health impacts. If $\mathrm{HQ} \leq 1$, indicates 
innocuous health influences and if HQ $>1$ suggested hurtful health influences. HI rate overall HQs and reveals the overall hazard of non-carcinogenic for solo poisonous mineral and again If $\mathrm{HI}$ less than one, refers to no hazard of non-carcinogenic influences, If HI more than one, points to non-carcinogenic effects [13].

\subsection{Statistical analysis}

Multivariate approaches were utilized to distinguish pollutant sources of minerals in road dusts through principal component analysis [14]. Pearson correlation (r2) between weighty minerals in the road dusts was accomplished in research. All mathematical and statistical computations on the dataset resulted utilizing SPSS 19.0 software (Chicago, Illinois, USA).

\section{Results and discussion}

Whole bioaccumulation metals levels in street dusts of Baghdad Mean concentrations of total and bioaccumulation of $\mathrm{Cd}, \mathrm{Cr}, \mathrm{Zn}$ and $\mathrm{Cu}$ from all the collection sites are presented in Table. 2. Zn Most prolific metals in streets dust succeed $\mathrm{Cu}, \mathrm{Cr}$ and $\mathrm{Cd}$, It has been noted that streets dust was significantly contributed to weighty mineral condensation grades in streets of civilian regions [15]. In general, $\mathrm{Zn}$ and $\mathrm{Cr}$ concentrations were found to be higher in streets of Adamiyah city (26.65 $\mathrm{mg} / \mathrm{kg}$ ) and the lowest level was in streets of Karada city $(2.57 \mathrm{mg} / \mathrm{kg})$. However, the results were lower than those reported in Tehran streets (Iran), Delhi streets (India) and Baoji streets (China) [16]. Weighted bioaccessible Zn condensations all specimens are much decrease than general $\mathrm{Zn}$ condensations ranging from highest in Jadriyah Street $(16.58 \mathrm{mg} / \mathrm{kg})$ to less Karada Street $(0.12 \mathrm{mg} / \mathrm{kg})$, increasing of Bio- $\mathrm{Zn}$ in study area is because high anthropogenic actions like battery factories, oil refinery which are concentrated in these locations. $\mathrm{Cd}$ was higher in Kinidi and Jihad streets than in other locations. In contrast, the minimum concentration of $\mathrm{Cd}(0.09 \mathrm{mg} / \mathrm{kg})$ was in Shaab Street. Moreover, Bio-Cd was also high in the same streets $(0.24,0.30 \mathrm{mg} / \mathrm{kg})$ due to these sites being closer to commercial activity or chemical industries which are more affected by extensive human activities. The concentrations of total and bioaccumulation of $\mathrm{Cu}$ were high in Dora streets $(24.22 ; 18.75 \mathrm{mg} / \mathrm{kg})$ that because metal-processing and power plant generation in the Dora city as well as brake abrasion from frequent brake use can be associated with increasing $\mathrm{Cu}$ level in the street [17].

In order to know level of metals contaminations in street dusts, we used Geo accumulation list (Igeo) suggested by Müller (1979) and which also utilized to evaluate grade of minerals pollution from civil street dusts $[4,10,13]$. The Igeo illustrated utilizing next one form (Müller, 1979):

Igeo $=\log 2\left(\frac{\mathrm{Cn}}{1.5 \mathrm{Bn}}\right)$
Table 2. Total and bioaccumulation of metals condensations in Dusts Roads in various cities in Baghdad (mg/kg)

\begin{tabular}{|l|l|l|l|l|l|l|l|l|}
\hline Sites & $\mathbf{C d}$ & $\begin{array}{l}\text { Bio } \\
-\mathbf{C d}\end{array}$ & $\mathbf{C r}$ & $\begin{array}{l}\text { Bio } \\
\mathbf{- C r}\end{array}$ & $\mathbf{Z n}$ & $\begin{array}{l}\text { Bio } \\
-\mathbf{Z n}\end{array}$ & $\mathbf{C u}$ & $\begin{array}{l}\text { Bio } \\
-\mathbf{C u}\end{array}$ \\
\hline Yarmo & 0.0 & 0.0 & 5.6 & 4.7 & 14. & 3.5 & 8.4 & 3.3 \\
uk & 4 & 04 & 8 & 2 & 87 & 8 & 2 & 0 \\
\hline Adami & 0.3 & 0.0 & 22. & 15. & 26. & 13. & 1.4 & 0.4 \\
yah & 9 & 06 & 40 & 58 & 65 & 88 & 3 & 9 \\
\hline Shaab & 0.0 & 0.0 & 1.5 & 0.5 & 18. & 2.4 & 17. & 11. \\
& 9 & 4 & 6 & 9 & 52 & 9 & 31 & 33 \\
\hline Wazir & 0.1 & 0.0 & 2.8 & 1.0 & 10. & 5.7 & 1.6 & 0.5 \\
eya & 3 & 6 & 7 & 7 & 12 & 9 & 6 & 9 \\
\hline Manso & 0.0 & 0.0 & 2.3 & 1.3 & 15. & 3.2 & 5.5 & 2.0 \\
ur & 03 & 01 & 8 & 1 & 97 & 9 & 5 & 7 \\
\hline Kindi & 1.3 & 0.2 & 3.6 & 2.1 & 7.1 & 4.3 & 14. & 8.7 \\
& 6 & 4 & 7 & 0 & 4 & 0 & 35 & 2 \\
\hline Jihad & 1.6 & 0.3 & 2.2 & 1.5 & 6.6 & 2.7 & 11. & 6.9 \\
& 0 & 0 & 2 & 1 & 2 & 5 & 78 & 6 \\
\hline Jadriy & 0.0 & 0.0 & 11. & 10. & 19. & 16. & 8.8 & 3.6 \\
ah & 8 & 04 & 53 & 06 & 58 & 58 & 1 & 3 \\
\hline Dora & 0.0 & 0.0 & 4.2 & 3.3 & 9.1 & 5.7 & 24. & 18. \\
& 05 & 01 & 8 & 7 & 8 & 0 & 22 & 75 \\
\hline Karad & 1.8 & 0.8 & 8.1 & 3.7 & 2.5 & 0.1 & 4.5 & 0.2 \\
a & 1 & 8 & 2 & 7 & 7 & 2 & 6 & 9 \\
\hline Total & 0.5 & 0.1 & 6.4 & 4.4 & 13. & 5.4 & 9.8 & 5.6 \\
mean & 5 & 5 & 7 & 0 & 12 & 8 & 0 & 1 \\
\hline
\end{tabular}

Cn calculated condensation of studied element $n$ in dust and $\mathrm{Bn}$ Geochemistry setting rate of items $\mathrm{n}$ of rate shale. Seven various grades of geo-accumulation list with connected dusts street dirtiness are given in the Table. 3 .

It has been showed that the concentrations of cadmium in the streets of Kennedy, Jihad and Dora were significantly higher than average rock rates, and based on Igyo found moderately contaminated to strong pollution on the same streets suggesting that human resources have a severe impact on the quality of these functional areas [18]. In addition, some weather conditions such as high temperature as well as reconstruction of the infrastructure of the city of Baghdad, lead to the wear of pots, dikes, bulbs and wall, often includes weighty minerals like $\mathrm{Zn}, \mathrm{Cu}, \mathrm{Cd}$ and $\mathrm{Cr}$, in the end, can lead These include emission of minerals into civilian climate and summation of dust in urban streets [19]. Hence, the region should pay attention to pollution in the future. On the other hand, Igeo of $\mathrm{Cr}, \mathrm{Zn}$, and $\mathrm{Cu}$ were at all sites of class 0 and $<0$ and therefore indicated that street dust could be considered unsaturated for these metals.

The relative availability of weighty minerals defined as rate of metals that can be obtained with respect to their total minerals, showed the contamination of absorbed minerals through the ingestion of dust as shown in Figure. 2. R-Bio$\mathrm{Cd}$ in the streets of dust, 1.70 and $51.8 \%$, while R-Bio-Cd showed high among these sampling sites in Al-Shaab Street. The value of R-Bio-Cr ranged from $37.4 \%$ to $87.2 \%$ and R-Bio-Cr was recorded high on Al-Jadriya Street. This may be related to social and economic procedures occurring in the trade section, there is great amount of length. constructing and height inhabitance intensity in the city of Baghdad [19]. Access to minerals in street dust from Iraq has not been reported for comparison with previous studies. Therefore, outcomes of research were contrast with different global studies. Relative ratios of zinc and 
copper that showed less than zinc and copper access (more than $90 \%$ ) of road dust and soil were recorded on the side of the road along a semi-urban area, Italy [18]. However, our results from Vital Bio Cr were higher than CR (5.83\%) of urban street dust in the mega city, Nanjing, China [19].

Table 3. The Igeo and classes of metals in Baghdad streets dust

\begin{tabular}{|c|c|c|c|c|c|c|c|c|}
\hline Sites & Cd & $\begin{array}{c}\text { Cl } \\
\text { as } \\
\text { s } \\
\end{array}$ & $\mathrm{Cr}$ & $\begin{array}{c}\text { Cla } \\
\text { ss }\end{array}$ & $\mathbf{Z n}$ & $\begin{array}{c}\mathrm{Cl} \\
\text { ass }\end{array}$ & $\mathbf{C u}$ & $\begin{array}{c}\text { Cla } \\
\text { ss }\end{array}$ \\
\hline $\begin{array}{c}\text { Yarmo } \\
\text { uk }\end{array}$ & $\begin{array}{c}- \\
3.3 \\
7\end{array}$ & 0 & $\begin{array}{l}- \\
4 . \\
57\end{array}$ & 0 & $\begin{array}{l}- \\
3 . \\
26\end{array}$ & 0 & $\begin{array}{c}- \\
3.0 \\
0\end{array}$ & 0 \\
\hline $\begin{array}{c}\text { Adami } \\
\text { yah }\end{array}$ & $\begin{array}{c}- \\
0.1 \\
9\end{array}$ & 0 & $\begin{array}{l}- \\
2 . \\
59\end{array}$ & 0 & $\begin{array}{l}- \\
2 . \\
41\end{array}$ & 0 & $\begin{array}{c}- \\
5.5 \\
6\end{array}$ & 0 \\
\hline Shaab & $\begin{array}{c}- \\
2.3 \\
2\end{array}$ & 0 & $\begin{array}{l}- \\
6 . \\
43\end{array}$ & 0 & $\begin{array}{l}- \\
2 . \\
94\end{array}$ & 0 & $\begin{array}{c}- \\
1.9 \\
6\end{array}$ & 0 \\
\hline $\begin{array}{c}\text { Wazire } \\
\text { ya }\end{array}$ & $\begin{array}{c}- \\
1.7 \\
9\end{array}$ & 0 & $\begin{array}{c}- \\
5 . \\
55\end{array}$ & 0 & $\begin{array}{l}- \\
3 . \\
81\end{array}$ & 0 & $\begin{array}{c}- \\
5.3 \\
4\end{array}$ & 0 \\
\hline $\begin{array}{l}\text { Manso } \\
\text { ur }\end{array}$ & $\begin{array}{c}- \\
7.0 \\
7 \\
\end{array}$ & 0 & $\begin{array}{r}- \\
5 . \\
82 \\
\end{array}$ & 0 & $\begin{array}{l}- \\
3 . \\
15 \\
\end{array}$ & 0 & $\begin{array}{c}- \\
3.6 \\
0\end{array}$ & 0 \\
\hline Kindi & $\begin{array}{c}1.5 \\
9\end{array}$ & 2 & $\begin{array}{l}- \\
5 . \\
19\end{array}$ & 0 & $\begin{array}{l}- \\
4 . \\
31\end{array}$ & 0 & $\begin{array}{c}- \\
2.2 \\
3\end{array}$ & 0 \\
\hline Jihad & $\begin{array}{c}1.8 \\
3\end{array}$ & 2 & $\begin{array}{c}- \\
5 . \\
92 \\
\end{array}$ & 0 & $\begin{array}{c}- \\
4 . \\
41\end{array}$ & 0 & $\begin{array}{c}- \\
2.5 \\
1\end{array}$ & 0 \\
\hline $\begin{array}{c}\text { Jadriya } \\
\text { h }\end{array}$ & $\begin{array}{c}- \\
2.4 \\
9 \\
\end{array}$ & 0 & $\begin{array}{l}- \\
3 . \\
54\end{array}$ & 0 & $\begin{array}{l}- \\
2 . \\
86\end{array}$ & 0 & $\begin{array}{c}- \\
2.9 \\
3 \\
\end{array}$ & 0 \\
\hline Dora & $\begin{array}{c}- \\
6.3 \\
1\end{array}$ & 0 & $\begin{array}{l}- \\
4 . \\
97 \\
\end{array}$ & 0 & $\begin{array}{l}- \\
3 . \\
95 \\
\end{array}$ & 0 & $\begin{array}{c}- \\
1.4 \\
7\end{array}$ & 0 \\
\hline Karada & $\begin{array}{c}2.0 \\
1\end{array}$ & 3 & $\begin{array}{l}- \\
4 . \\
05\end{array}$ & 0 & $\begin{array}{l}- \\
5 . \\
78\end{array}$ & 0 & $\begin{array}{c}- \\
3.8 \\
8\end{array}$ & 0 \\
\hline $\begin{array}{c}\text { Avera } \\
\text { gea } \\
\text { shale }\end{array}$ & $\begin{array}{c}0.3 \\
0\end{array}$ & 0 & 90 & 0 & 95 & 0 & 45 & 0 \\
\hline
\end{tabular}

\subsection{Multivariate statistical analysis}

Correlations and PCA analysis between heavy metals The Pearsons correlation coefficients (r2) and principal component analysis (PCA) weighty minerals in the street dust of Baghdad showed in Shape. 5. Significant positively correlation between $\mathrm{Zn}, \mathrm{Cd}$ and $\mathrm{Cr}(-0.631,0.600 ; \mathrm{p}<0.01)$ respectively, indicated that major common source of metals are artificial performances like manufacturing, trade vehicular, traffic performances. $\mathrm{Cu}$ was negative correlated with $\mathrm{Cr}(-0.449 ; \mathrm{p}<0.05)$ and other correlated between metals was not showed relationship with each other indicated different sources of origin. PCA has been implemented to determine the proportion of contributions from various heavy metals sources to a particular sample of dust. The value of KMO experiment 0.43 , and the Bartlett ball experiment statistically important $(p<.000)$, mentioning information probably to be changeable. PCA Metal detected two components with a value greater than one eigenvalues. Two components were extracted, accounting for $82.37 \%$ all difference, mentioning weighty mineral references can be split into two categories (Table 4). The first component of $\mathrm{Cd}$ and $\mathrm{Zn}$ consists of the fact that $\mathrm{Cd}$ and $\mathrm{Zn}$ originate from the same sources, and $\mathrm{Zn}$ can arise again from top tyres corrosion and erosion of wheel car accessories. Cadmium may also produce benzene compounds in the streets [20]. The second component consists of $\mathrm{Cr}$ and $\mathrm{Cu}$, and this component formed the constituent components of man. $\mathrm{Cr}$ and $\mathrm{Cu}$ sources can be affected by metal processing industries and congested traffic.

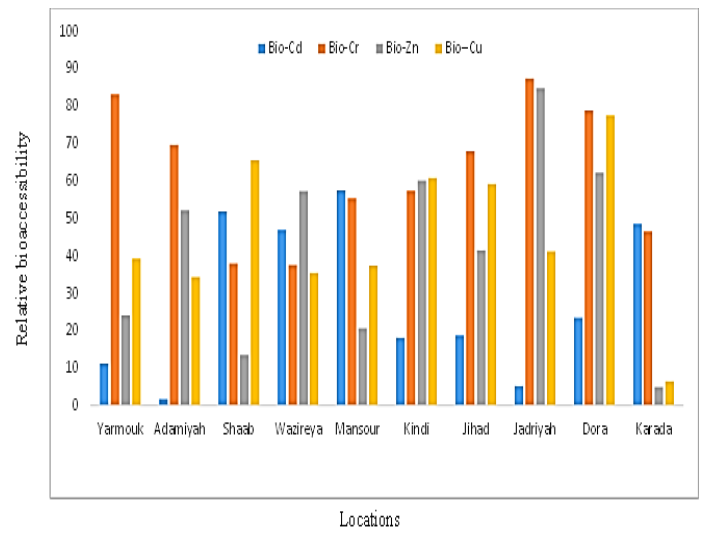

Fig. 2. Extractable relative bioaccumulation of heavy metals from Street dust at Baghdad city

Table 4. Pearsons correlation coefficients and main ingredient test between weighty minerals (PCA cargos $>0.7$ illustrated in bold)

\begin{tabular}{|c|c|c|c|c|}
\hline & $\mathrm{Cd}$ & $\mathrm{Cr}$ & $\mathrm{Zn}$ & $\mathrm{Cu}$ \\
\hline $\mathrm{Cd}$ & 1 & & & \\
\hline $\mathrm{Cr}$ & -0.060 & 1 & & \\
\hline $\mathrm{Zn}$ & $-0.631^{* *}$ & $\begin{array}{c}0.600^{*} \\
*\end{array}$ & & \\
\hline $\mathrm{Cu}$ & -0.081 & $-0.449 *$ & -0.233 & 1 \\
\hline Elements & $\begin{array}{c}\text { Compon } \\
\text { ent }\end{array}$ & 1 & & \\
\hline $\mathrm{Cd}$ & -0.927 & 0.144 & 0.880 & \\
\hline $\mathrm{Cr}$ & 0.284 & 0.836 & 0.780 & \\
\hline $\mathrm{Zn}$ & 0.842 & 0.447 & 0.909 & \\
\hline $\mathrm{Cu}$ & 0.114 & -0.845 & 0.727 & \\
\hline $\begin{array}{c}\text { Eigenvalue } \\
\% \text { of } \\
\text { variance } \\
\text { explained }\end{array}$ & 2.032 & 1.263 & & \\
\hline $\begin{array}{c}\% \text { of } \\
\text { cumulative }\end{array}$ & 41.540 & 40.837 & & \\
\hline * $<<0.05$ \\
$* *$ p $<0.01$
\end{tabular}

\subsection{Health hazard assessment of heavy minerals}

In order to be determined the risk assessment, both carcinogenic and non-carcinogenic hazards was estimated to kids and adolescents from absorbing road dusts, health 
hazard utilized to illustrated the population of the city was shown in Table. 5 and (Supplementary data Table S1).

Risk division (HQ) rate $\mathrm{Cr}$ and $\mathrm{Cu}$ for both adolescents and kids were high, between 0.0004 to 0.026 and $25 \times 10$ 5 to 0.031 respectively but are lowest safe rate $(\mathrm{HQ}=1)$ so far. Metals in street dusts for adolescents and kids are not likely non-carcinogenic health hazard ( $\mathrm{HI}>1$ ), for adults, the HI values of the human exposure to dust for metals studied are represented by $\mathrm{Cu}>\mathrm{Zn}>\mathrm{Cr}>\mathrm{Cd}$ and for children by $\mathrm{Cr}>\mathrm{Cu}>\mathrm{Cd}>\mathrm{Zn}$ decreasing series [21].

The HI for non-carcinogenic effects in kids lowered because $\mathrm{Cr}>\mathrm{Cu}>\mathrm{Cd}>\mathrm{Zn}$, same order decreased for adults $\mathrm{Cr}>\mathrm{Cu}>\mathrm{Cd}>\mathrm{Zn}$, the $\mathrm{HI}$ of metals were less than the safe level, suggested that metals in street dusts of Baghdad city posed a little health risks. The high values for $\mathrm{Cr}$ in Baghdad street dusts may impose adverse health in the future for human population especially for children (0.47). The results of non-carcinogenic and carcinogenic hazards of minerals from Baghdad road dusts serious health assessment, due to used metals bioaccumulation concentrations is accurately and absolutely necessary to estimate health risks [22].

Table 5. Non-carcinogenic and carcinogenic health risk of weighty minerals in street dusts

\begin{tabular}{|c|c|c|c|c|c|c|c|}
\hline \multirow{2}{*}{$\begin{array}{c}\text { Ele } \\
\text { men } \\
t\end{array}$} & \multirow{2}{*}{$\begin{array}{c}\text { Conce } \\
\text { ntrati } \\
\text { on } \\
\end{array}$} & \multicolumn{2}{|c|}{ HQ } & \multicolumn{2}{|c|}{ HI ( $\sum$ HQ) } & \multicolumn{2}{|c|}{ CR } \\
\hline & & $\begin{array}{l}\text { Ado } \\
\text { lesc } \\
\text { ent }\end{array}$ & $\begin{array}{c}\mathrm{Ki} \\
\mathrm{d}\end{array}$ & $\begin{array}{l}\text { Ado } \\
\text { lesc } \\
\text { ent }\end{array}$ & Kid & $\begin{array}{l}\text { A } \\
\text { do } \\
\text { les } \\
\text { ce } \\
\text { nt }\end{array}$ & Kid \\
\hline $\mathrm{Cd}$ & 0.55 & $\begin{array}{l}3.33 \\
\text { E-04 }\end{array}$ & $\begin{array}{c}0.0 \\
00 \\
6\end{array}$ & $\begin{array}{c}3.33 \\
\text { E- } \\
03\end{array}$ & $\begin{array}{c}0.00 \\
6\end{array}$ & $\begin{array}{l}3 . \\
18 \\
\text { E- } \\
07\end{array}$ & $\begin{array}{l}5.93 \\
\text { E-07 }\end{array}$ \\
\hline $\mathrm{Cr}$ & 6.47 & $\begin{array}{c}0.02 \\
53\end{array}$ & $\begin{array}{c}0.0 \\
47 \\
3\end{array}$ & $\begin{array}{c}2.54 \\
\text { E- } \\
01\end{array}$ & $\begin{array}{c}0.47 \\
3\end{array}$ & $\begin{array}{c}8 . \\
38 \\
\text { E- } \\
06\end{array}$ & $\begin{array}{l}1.56 \\
\text { E-05 }\end{array}$ \\
\hline $\mathrm{Zn}$ & 13.1 & $\begin{array}{c}0.00 \\
04\end{array}$ & $\begin{array}{c}0.0 \\
00 \\
8\end{array}$ & $\begin{array}{c}0.00 \\
4\end{array}$ & $\begin{array}{c}0.00 \\
8\end{array}$ & & \\
\hline $\mathrm{Cu}$ & 9.81 & $\begin{array}{c}0.00 \\
34\end{array}$ & $\begin{array}{c}0.0 \\
06 \\
4\end{array}$ & $\begin{array}{c}0.03 \\
4\end{array}$ & $\begin{array}{c}0.06 \\
4\end{array}$ & & \\
\hline
\end{tabular}

\section{Conclusion}

The street dust in Baghdad has elevated levels of four metals $(\mathrm{Cd}, \mathrm{Cr}, \mathrm{Zn}$ and $\mathrm{Cu})$. The findings of this study indicated that Karada, Jihad and Kindi are highly contaminated by $\mathrm{Cd}$-from street dust. An in vitro digestion model utilized to measure bioaccessible fraction of minerals in the road dust. R-Bio-Cd was quite low in the Karada Street and higher for R-Bio-Cr in Jadriyah Street. The different bioaccumulation values in Baghdad streets are associated with the differences in anthropogenic activities sources. The correlation coefficient and main ingredient test - employed to know possible references of weighty minerals studied in road dust. $\mathrm{Cd}, \mathrm{Zn}$ are from the same sources originated from tyre wear, brake wearweighty transit, while $\mathrm{Cr} \mathrm{Cu}$ originated from metal processing industries. Whole bioaccumulation of weighty minerals results were used in the calculation of human health risks, and HI (children and adults) was within safe levels. These results can help us to get a better insight into potential health risks to Baghdad residents [23].

\section{References}

1. Bilos, C., Colombo, J. C., Skorupka, C. N., Rodriguez Presa, M. J., (2001). Sources, distribution and variability of air borne trace metals in LaPlata City area, Argentina. Environ. Pollut.111, 149-158.

2. Manno, E., Varrica, D., Dongarrà, G., (2006). Metal distribution in road dust samples collected in an urban area close to petrochemical plant at Gela, Sicily. Atmos. Environ. 40, 5929-5941.

3. Leopold E, Jung M, Auguste O, Ngatcha N, Georges E, Lape M. (2008). Metals pollution in freshly deposited sediments from river Mingoa, main tributary to the Municipal lake of Yaounde, Cameroon. Geos J 12:337-347.

4. Huang J. (2016). Integrating hierarchical bioavailability and population distribution into potential eco-risk assessment of heavy metals in road dust: a case study in Xiandao District, Changsha city, China. Science of The Total Environment 541: 969976.

5. Liu, A., Liu, L., Li, D.Z., Guan, Y.T., 2015. Characterizing heavy metal build-up on urban road surfaces: implication for storm water reuse. Sci. Total Environ. 515-516, 20-29.

6. Shi, G.T., Chen, Z.L., Xu, S.Y., Zhang, J., Wang, L., Bi, C.J., Teng, J.Y., 2008. Potentially toxic metal contamination of urban soils and roadside dust in Shanghai, China. Environ. Pollut. 156,251-260.

7. Wei, B.G., Yang, L.S., 2010. A review of heavy metal contaminations in urban soils, urban road dusts and agricultural soils from China. Microchem. J. 94, 99107.

8. Pan, H. Lu, X. Lei, K. (2017). A comprehensive analysis of heavy metals in urban road dust of Xi'an, China: Contamination, source apportionment and spatial distribution. Science of the Total Environment. 609: 1361-1369.

9. Ruby, M. V., Schoof, R., Brattin, W., Goldade, M., Post, G., Harnois, M., Mosby, D. E., Casteel, S. W., Berti, W., Carpenter, M., Edwards, D., Cragin, D., and Chappell, W. (1999). A dvances in evaluating the oral bio- availability of inorganics in soil for use in human health risk assessment. Environ. Sci. Technol. 33:3697-3705.

10. Schroder, J., Basta, N., Casteel, S., Evans, T., Payton, M., Si, J., (2004). Validation of the in vitro gastrointestinal (IVG) method to estimate relative bioavailable lead in contaminated soils. J Environ Qual 33, 513-521. 
11. Trujillo-González, J. M., Torres-Mora, M. A., Keesstra, S., Brevik, E. C., Jiménez-Ballesta, R. (2016). Heavy metal accumulation related to population density in road dust samples taken from urban sites under different land uses. Science of the Total Environment 553: 636-642.

12. Charlesworth, S., Everett, M., McCarthy, R., Ordonez, A., DeMiguel, E., (2003). A comparative study of heavy metal concentration and distribution in deposited street dusts in a large and a small urban area: Birmingham and Coventry, West Midlands, UK. Environ. Int. 29 (5), 563-573.

13. Karimi, N., Ghaderian, S.M., Maroofi, H., Schat, H., (2009). Analysis of arsenic in soil and vegetation of a contaminated area in Zarshuran, Iran. Int. j. phytoremediat. 12 (2), 159-173.

14. Sparks, D.L., Page, A.L., Helmke, P.A., Loeppert, R.H., Soltanpour, P.N., Tabatabai, M.A., Sumner, M.E., (1996). Methods of soil analysis. Part 3Chemical methods. Soil Science Society of America Inc.

15. Han, Y.M., PX, Du, Cao, J.J., Posmentier, E.S., (2006). Multivariate analysis of heavy metal contamination in urban dusts of Xi'an, Central China. Sci. Total Environ. 355, 176-186.

16. Li, H.H., Chen, L.J., Yu, L., Guo, Z.B., Shan, C.Q., Lin, J.Q., et al., (2017). Pollution characteristics and risk assessment of human exposure to oral bioaccessibility of heavy metals via urban street dusts from different functional areas in Chengdu, China. Sci. Total Environ. 586: 1076-1084.

17. Karanasiou, A.A., Siskos, P.A., Eleftheriadis, K., (2009). Assessment of source apportionment by positive matrix factorization analysis on fine and coarse urban aerosol size fractions. Atmos. Environ. 43 (21), 3385-3395.

18. Abed S. Ali et al 2019 J. Phys.: Conf. Ser. 1294 072025.

19. Ewaid, S.H.; Abed, S.A.; Al-Ansari, N. Water Footprint of Wheat in Iraq. Water 2019, 11, 535.

20. Athanasopoulou, E., Tombrou, M., Russell, A.G., Karanasiou, A., Eleftheriadis, K., Dandou, A., (2010). Implementation of road and soil dust emission parameterizations in the aerosol model CAMx: applications over the greater Athens urban area affected by natural sources. J. Geophys. Res. 115, D17301.

21. Kadhim J L Al-Zaidy et al 2019 J. Phys.: Conf. Ser. 1294072021.

22. Ewaid, S.H.; Abed, S.A.; Al-Ansari, N. Crop Water Requirements and Irrigation Schedules for Some Major Crops in Southern Iraq. Water 2019, 11, 756.

23. Kamani, H., Mahvi, A. H., Seyedsalehi, M., Jaafari, J., Hoseini, M., Safari, G. H., Dalvand, A., Aslani, H., Mirzaei, N., Ashrafi, S., D. (2017). Contamination and ecological risk assessment of heavy metals in street dust of Tehran, Iran. Int. J. Environ. Sci. Technol. 14 (12) 2675-2682. 